\title{
Increasing Social Skill Children Aged 4-5 With the Chaterpillar Game
}

\author{
Anita Damayanti ${ }^{\circledR}$, Nita Priyanti², Iswan ${ }^{1,}$ Lia Rahmawati ${ }^{1}$ \\ Pendidikan Guru Pendidikan Anak Usia Dini, Universitas Muhammadiyah Jakarta, \\ Indonesia(1); Pendidikan Guru Pendidikan Anak Usia Dini, Universitas Panca Sakti Bekasi, \\ Indonesia(2) \\ DOI: $\underline{10.31004 / o b s e s i . v 6 i 3.1855}$
}

\begin{abstract}
This research is a collaborative classroom action research using the Kemmis and McTaggart models. The research subjects were children aged 4-5 years, totaling 6 children. The object of this research social skills. The data collection method used was observation. The instrument used is an observation guide. Data analysis techniques were carried out descriptively, qualitatively and quantitatively. The success indicator set is that at least $80 \%$ of 6 children have social skills with the criteria for developing as expected. At the time of pre-action observation, the initial condition of early childhood social skills in the Buaran area before the action research was still very low where children who could carry out, namely twenty two point five percent. In the first cycle with the achievement of the percentage of fourty seven point five percent until fifty five point five percent.
\end{abstract}

Keyword: social skills; caterpillar game; early childhood

\begin{abstract}
Abstrak
Penelitian ini merupakan penelitian tindakan kelas kolaboratif dengan model Kemmis dan McTaggart. Subjek penelitian adalah anak usia 4-5 tahun yang berjumlah 6 anak. Objek penelitian ini adalah keterampilan sosial. Metode pengumpulan data yang digunakan adalah observasi. Instrumen yang digunakan adalah pedoman observasi. Teknik analisis data dilakukan secara deskriptif, kualitatif dan kuantitatif. Indikator keberhasilan yang ditetapkan adalah minimal 80\% dari 6 anak memiliki keterampilan sosial dengan kriteria berkembang sesuai dengan yang diharapkan. Pada saat observasi pra tindakan, kondisi awal keterampilan sosial anak usia dini di wilayah Buaran sebelum penelitian tindakan masih sangat rendah dimana anak yang bisa melaksanakan yaitu dua puluh dua koma lima persen. Pada siklus I dengan pencapaian persentase empat puluh tujuh koma lima persen sampai dengan lima puluh lima koma lima persen.
\end{abstract}

Kata Kunci : keterampilan social; permainan ulat bulu; anak usia dini

Copyright (c) 2021 Anita Damayanti, et al.

$\triangle$ Corresponding author:

Email Address : anita.damayanti@umj.ac.id (Jakarta, Indonesia)

Received 11 August 2021, Accepted 12 November 2021, Published 17 January 2021 


\section{INTRODUCTION}

Social skills are very important to help children make friends, become friends, and this contributes to their quality of life and future success. One that supports children's social intelligence is to train children's emotional intelligence. Social skills can be seen in several forms behavior: first, behavior related to oneself intrapersonal) such as controlling emotions, solving social problems precise, processing information and understanding the feelings of others; second, behavior relating to other people (interpersonal in nature) such as starting interaction and communication with other people; and three related behaviors academically, such as obeying the rules and doing what is asked by the teacher.Children are a very valuable treasure for every parent, children have many colors that can brighten up every family. Where children are a gift from God that we must educate properly and correctly. By instilling religious and scientific values for their future life.

Early Childhood Education is essentially an education organized with the aim of facilitating the growth and development of children as a whole which emphasizes the development of all aspects of the child's personality. Children aged 4-5 years are part of early childhood in the preschool stage. As stated in the law on the national education system, it is stated that early childhood education is a coaching effort aimed at children from birth to the age of 6 years which is carried out through the provision of educational stimuli to assist physical and spiritual growth and development so that children have readiness in entering further education other non-formal education channels. One of the development of behavioral attitudes is the development of children's social skills according to their stage of development.

Besides that, the social skills of children aged 4-5 years are also based on developmental characteristics, namely social skills such as working together, sharing, interacting, and helping each other. Children who initially only interact with the home environment, at this age children interact with the wider environment, such as school. As the child's social environment increases, the number of people who interact with each other increases and the attitudes of each person are different, so that at an early age the skills to adapt begin to develop.

Based on pre-study it was found that children's social abilities had not developed as expected. For example, children still have difficulty in working together. Some children during free play activities prefer to be alone with their favorite toys than playing with their friends. Another problem is that when playing, children fight over toys, they don't want to help friends who are having trouble or don't want to tidy up the toys after they are used. In the research place there are 6 children accompanied by 1 teacher and 1 assistant. Of the many children, 6 of them often do bad behavior when playing. So the teacher must often direct the children when they play. In accordance with the role of the teacher who helps to develop various aspects of development contained in the child optimally. Social skills are important to be developed, so that children can easily interact with their peers and the surrounding environment. There are various ways that can be done by choosing the method of playing group games.

Based on previous research, in this study one of the methods used to improve children's skills is through The Chaterpillar Game.The Chaterpillar Gameis a group game so it is hoped that children will be able to carry out social interactions with their friends, especially in communicating and being responsible for passing obstacles in Snakes and ladders game.

The Chaterpillar Gameis made of cardboard media that is modified into a shape like a caterpillar and decorated with various types of flannel to make it more attractive to children and more similar to the original caterpillar. With this game, children can communicate to work together, walk hand in hand, march through obstacles like caterpillars. It is hoped that through this caterpillar game, children will communicate with each other more often, work together through obstacles, so that they are expected to be able to develop and improve children's social skills. 
Seeing the problems above, how important it is that the author is interested in conducting action research on The Chaterpillar Gamemethod made of cardboard as an effort to improve children's social skills. Therefore, from the problems that have been studied and analyzed with various considerations and perspectives that can thoroughly explore the existing problems, the researchers decided on the title of this study, namely "Improving the Social Skills of 4-5 Years Old Children Through Snakes and ladders game

\section{METHODOLOGY}

The method used in the study to collect research data is collaborative classroom action research using the Kemmis and Mc Taggart model because in this study we will provide treatment with the snake game as a change in improving social skills in the class to be studied. The research subjects were children aged 4-5 years, totaling 6 children. The data collection method used was observation. The instrument used is a social skill observation guide whose instruments have been validated by experts. Data analysis techniques were carried out descriptively, qualitatively and quantitatively.

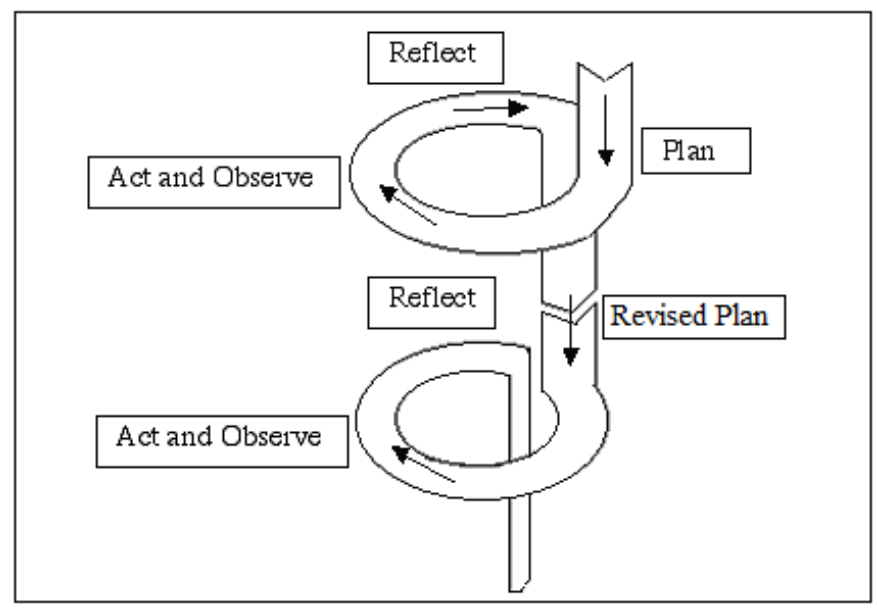

Picture 1. Classroom Action Research Kemmis and Mc Taggart

\section{RESULTS AND DISCUSSION}

The implementation of the first cycle as well as analyzing to draw conclusions on the achievement of the development of early childhood social skills in the Buaran area before the action research was carried out was still below the standard of achievement of early childhood in general. The conclusion is the achievement of social skills development in children is $37.5 \%$ and $40 \%$. The second test of the children are still low at $22.5 \%$.

The results of the first cycle of observations then measured the level of progress success of the child through the data interpreted analyzed, then with full attention to groups that have problems. The results obtained after the implementation of the caterpillar playing activity to train to develop emotional social skills with the theme Animals sub-theme types of animals, namely there are 6 children between 2 groups there are children whose development is still less than 6 children, only 2 children who begin to show their social intelligence. In the first cycle of playing caterpillar activities to provide children's emotional social skills achievement, the results were not as expected, children were found to be still not active in playing, there were still children who had not focused on playing and there were still children who were less enthusiastic in playing..

This happens because the child is not stimulated properly. Finally, the supervisor explains and gives encouragement and motivation to the children the purpose and objectives of the caterpillar playing activities carried out in groups. From the percentage of results above, it shows that in the first cycle the children's success will be followed up in the second cycle, 
which means that the social skills achieved by the children are still not in line with the writer's expectations. Therefore, follow-up for improvements in improving social skills through caterpillar games can be carried out in the next cycle.

This action is based on the results of the first cycle of observations and then measured the level of progress and success of children through the data obtained and interpreted and analyzed, then with full attention to problematic individuals. The results of Cycle 2 Playing Caterpillar play activities as a whole have reached the indicators that have been set on the observation sheet. A conducive learning process and caterpillar games are very effective in growing the Social Skills of children aged 4-6 years. It can be seen in cycle 2 that children are active in playing caterpillars, children are already focused on playing, and children's interest is growing in playing caterpillars. The results of the assessment of observations on the activities of children and cycle 2 counselors have increased results as expected. This shows that learning activities through caterpillar games can improve the social skills of children aged 4-6 years. From the results of observations in cycle 2 of learning in Snakes and ladders game, there were 4 children who experienced a significant increase in playing and 2 children who were active in playing.

The results of the recapitulation of observations in the Pre-Cycle, Cycle 1, and Cycle 2 can be seen in the graph in picture 1.

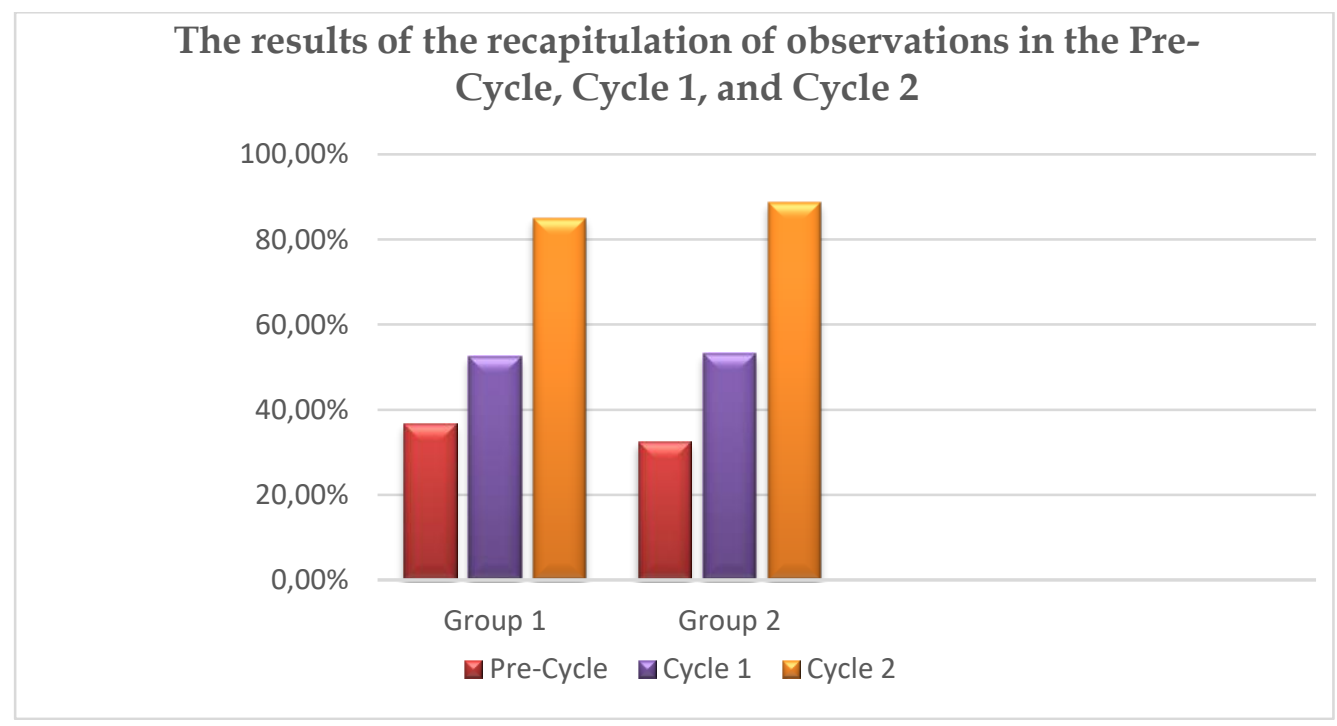

Picture 1. The results of the recapitulation of observations in the Pre-Cycle, Cycle 1, and Cycle 2

\section{Discussion}

Several research results have been carried out in an effort to improve the social skills of early childhood through various play activities, including through development games using blocks and plastisin media by Yuliatiningsih (2016) and traditional games by Perdani (2014) focusing on children's social skills in communicating, being responsible. , and work together. In contrast to this study, which used a caterpillar game made of cardboard which was modified into a shape resembling a real caterpillar and decorated with colorful flannel to attract children's attention.

The results of the research obtained illustrate that the social skills of children aged 4 to 5 years can be improved through the Caterpillar game, with the achievement of a percentage of $47.5 \%-55.5 \%$ in cycle 1 and reaching $75 \%$ - 95\% in cycle 2 . These social skills include aspects of imitation skills, competition, cooperation, sympathy, empathy, social support, sharing and friendly behavior. The following is a more detailed description of each indicator on the social skills aspect of each cycle. Figure 2 shows the results of children's activities in cycle 1. 


\begin{tabular}{|c|c|c|c|c|c|c|c|c|c|c|c|}
\hline \multirow[b]{2}{*}{$\begin{array}{l}\text { 客 } \\
\text { 选 }\end{array}$} & & \multicolumn{10}{|c|}{ ASPECT / NDICATORE } \\
\hline & 䚁 & 罢 & 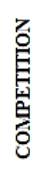 & 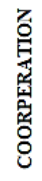 & 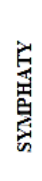 & 畜 & 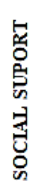 & 穿 & 惫 & 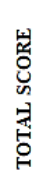 & $\begin{array}{l}\text { 넌 } \\
\text { 离 } \\
\text { 兽 }\end{array}$ \\
\hline \multirow{3}{*}{1} & Rо & 3 & 3 & 2 & 3 & 2 & 3 & 2 & 3 & 21 & $52,50 \%$ \\
\hline & $A Y$ & 3 & 3 & 3 & 2 & 3 & 3 & 3 & 3 & 23 & $57,50 \%$ \\
\hline & AM & 2 & 2 & 3 & 2 & 2 & 2 & 3 & 3 & 19 & $47,50 \%$ \\
\hline \multirow{3}{*}{2} & ${ }_{A T}$ & 3 & 3 & 3 & 3 & 2 & 3 & 2 & 3 & 22 & $55,00 \%$ \\
\hline & Pr & 3 & 3 & 2 & 2 & 3 & 3 & 3 & 3 & 22 & $55,00 \%$ \\
\hline & A7. & 3 & 2 & 3 & 2 & 2 & 2 & 3 & 2 & 19 & $49,50 \%$ \\
\hline
\end{tabular}

Picture 2. The results of the recapitulation of observations in the Cycle 1

In cycle 1 , the development of children's emotional social skills was carried out in a play program with the theme Animals, sub-theme types of animals, while the results obtained from 6 children who played, only 2 children saw the development of social intelligence. This has not met the targeted expectations. There are still children who look not active and not enthusiastic in playing because the children have not been given encouragement or motivation by the teacher about the benefits of playing Caterpillars with friends in a group. The percentage of the results of increasing children's emotional social skills in cycle 1 is $47.5 \%$ $55.5 \%$. This has not met the predetermined achievement target, therefore the second cycle was carried out.

Before the second cycle activity was carried out, each child was given motivation about the benefits of playing in the caterpillar game. This motivational provision aims to make children more enthusiastic and happy to play together. Based on the results of observations during the playing process, it can be seen that there is a very significant increase in children's emotional social skills, this can be seen in Figure 3 below :

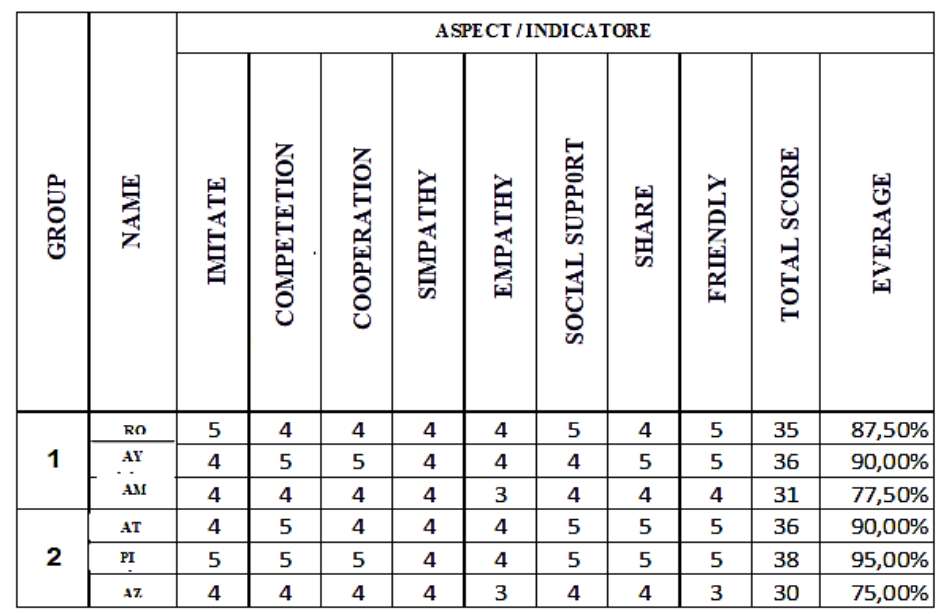

Picture 3. The results of the recapitulation of observations in the Cycle 2

Based on the observations in the second cycle, the six children looked very active and focused in playing caterpillars. This illustrates that children are very interested in playing, so that the increase in children's social and emotional skills increases by $75 \%-95 \%$. Thus, the cycle is stopped because it has reached the desired target.

Play is a basic need of children, because through playing children can develop all the potential that exists in themselves. Not only social-emotional development, but also moral- 
religious development, motor (gross-fine), language, cognitive and artistic development of children. Likewise with this caterpillar game, all parts of the game activity can stimulate the six aspects of child development. The habit of reading prayers before and after playing activities and explaining the small caterpillar creature as one of God's creatures can develop religious values in children. A sportsmanship attitude to admit defeat in a game can also develop a child's commendable attitude. The movement of walking and twisting while holding hands by holding the shoulders of a friend in front of him, following the way the caterpillar walks is a stimulation for the development of children's gross motor skills. Saying colors and bringing a number of seeds according to the numbers listed on the number cards in the game, stimulates children's cognitive and language development, and hums singing the dragon's song to the rhythm of the caterpillar's walking is a stimulation of children's artistic development. Based on the caterpillar game activities above, it can be seen that the teacher does not only aim to improve social emotional development but this game can also stimulate all aspects of child development.

Caterpillar games can also develop a child's executive function. Recognizing colors and symbols of numbers on cards, helps children train visual perception and enlarges the working memory capacity of the brain. Children's serious attitude (diligent) to complete group tasks while playing, train self-control, discipline and control attention. The ability to take a number of seeds according to the numbers listed on the card correctly is a problem solving exercise (cognitive flexibility)

\section{CONCLUSION}

This study shows that caterpillar game activities can improve children's social skills through various interactions when children play games by (1) dividing play activities by themselves (2) taking turns while playing (3) queuing for their turn while playing and (4) skills when playing games. Thus, it can be concluded that social skills can increase through the caterpillar game activity in Buaran Village, Serpong District, South Tangerang.

\section{ACKNOWLEDGMENTS}

We would like to thank LPPM University Muhammadiyah of Jakarta and Panca Sakti University Bekasi who have provided funding for this research.(Adani \& Hidayah, 2015)

\section{REFERENCES}

A Hamdani. (2010). Strategi Belajar Mengajar. CV Pustaka Setia.

Achroni, Keen. (2012). Mengoptimalkan Tumbuh Kembang Anak Melalui Permainan Tradisional. Jakarta : Javalitera.

Adani, D. N., \& Hidayah, I. T. (2015). Permainan Tradisional Ular Naga. 1-12. https:// studylibid.com/doc/528896/makalah-permainan-tradisional-ular-naga

Carol \& Barbara. (2008). Pendidikan Anak Usia Dini. PT. Macanan Jaya Cemerlang.

Daoudi, M. (2000). Peningkatan Keterampilan Sosial Anak Usia 4-5 Tahun Melalui Permainan

Bola Estafet Di Tpa Permata Bunda Semarang Tahun Ajaran 2015/2016. Journal of

Visual Languages \& Computing, 11(3), 287-301. https:// doi.org/10.1006/jvlc.2000.0159

Deasy Anugrahwati, Marmawi R, Y. (2013). Peningkatan Keterampilan Sosial Melalui Metode

Bermain Peran Pada Anak Usia $4 \pm 5$ Tahun. Journal of Chemical Information and Modeling, 53(9), 1689-1699.

Fakhriyani, D. V. (2018). Pengembangan Keterampilan Sosial Anak Usia Dini Melalui Permainan Tradisional Madura. Jurnal PG-PAUD Trunojoyo : Jurnal Pendidikan Dan Pembelajaran Anak Usia Dini, 39-44. https://doi.org/10.21107/pgpaudtrunojoyo.v5i1.3685

Hurlock, Elizabeth. 1978. Perkembangan Anak. Jakarta. Gramedia 
Ismail, A. (2009). Education Games Menjadi Cerdas dan Ceria dengan Permainan Edukatif. Pilar Media.

Mayke S, Tedajasaputra. (2001). Bermain, Mainan dan Permainan untuk Pendidikn Anak Usia Dini. Jakarta: Grasindo

Muslich, M. (2010). Melaksanakan PTK Itu Mudah. Bumi Aksara.

Nugraha. (2014). Panduan Praktis Penelitian Kualitatif. Angkasa.

Perdani, P. A. (2014). Peningkatan keterampilan sosial anak melalui permainan tradisional. Jurnal Pendidikan Usia Dini, 8(1), 129-136.

Rahayu, D., Hamid, S. I., \& Sutini, A. (2014). Peningkatan Keterampilan Sosial Anak Usia Dini Melalui Permainan Tradisional. Cakrawala Dini: Jurnal Pendidikan Anak Usia Dini, 7(2), 129-136. https://doi.org/10.17509/cd.v7i2.10527

Rosma Hartiny Sam's. (2010). Model Penelitian Tindakan Kelas. Teras.

Sugiyono. (2012). Metode Penelitian Pendidikan, Pendekatan Kuantitatif,Kualitatif dan R\&D. Alfabeta.

susanto, ahmad. (2011). Perkembangan Anak Usia Dini. PT. Kencana Prenada Media Group.

Tampubolon, S. (2014). Penelitian Tindakan Kelas Sebagai Pengembangan Profesi Pendidik dan Keilmuan. Airlangga.

Wiraatmadja, R. (2002). Metode Penelitian. Penerbit Rineka Cipta.

Yuliatiningsih, N., Saparahayuningsih, S., \& Sumarsih, S. (2016). Meningkatkan Keterampilan Sosial Melalui Bermain Pembangunan Pada Anak Usia Dini Di Kelompok B Raudhatul Athfa Habibilah Pekik Nyaring Blok Iii Bengkulu Tengah. Jurnal Ilmiah Potensia, 1(2), 84-91. https://doi.org/10.33369/jip.2.2 